\title{
Head Measurements for the Diagnosis of Craniosynostosis
}

\section{As medidas cranianas no diagnóstico das craniossinostoses}

José Aloysio CostaVal ${ }^{1,2}$ Leopoldo Furtado Mandic ${ }^{1}$ Sebastião Nataniel Gusmão ${ }^{2}$

${ }^{1}$ Department of Pediatric Neurosurgery, Biocor Instituto, Nova Lima, MG, Brazil

${ }^{2}$ School of Medicine, Universidade Federal de Minas Gerais (UFMG),

Address for correspondence José Aloysio CostaVal, MD, Pediatric Neurosurgery, Biocor Instituto, Av. Alameda da Serra, 322/408. Nova Belo Horizonte, MG, Brazil

Arq Bras Neurocir 2017;36:91-95.

\begin{abstract}
Keywords

- child care

- diagnostic recommendations

- craniosynostosis and head circumference

\section{Resumo}

Palavras-chave

- cuidado infantil

- recomendações de diagnóstico

- craniossinostoses e perímetro cefálico

Objective Craniosynostosis is a group of growth disturbances of the skull, which can result in serious consequences for the children who suffer from it. Early diagnosis provides treatment at the correct time. Most of the time, the pediatrician uses the head circumference $(\mathrm{HC}$ ) as a parameter for the diagnosis, but the $\mathrm{HC}$ does not appear to be changed in this disease, leading to incorrect interpretations. The anteroposterior distance (APD) and biauricular distance (BAD) appear to be more accurate. The aim of this study is to analyze the value of the $\mathrm{HC}$ and the ratio between the measurements of the APD and the BAD for this diagnosis.

Methods We analyzed the data from 129 children who had already undergone an operation for craniosynostosis at an institution in Southeastern Brazil. These data were compared with the normal standards of the population and statistically analyzed to establish their alterations.

Results The HC did not change significantly in cases of craniosynostosis, neither when it was considered as a single disease, nor when considering the different subtypes. The APD/BAD ratio changed significantly in the group.

Conclusion The HC does not appear to be useful in the diagnosis of craniosynostosis as an individual parameter. The APD/BAD ratio appears to help in the diagnosis.

Objetivo Craniossinostoses são alterações do crescimento do crânio que podem resultar graves consequências para a criança. O diagnóstico precoce propicia o tratamento correto. O perímetro cefálico $(\mathrm{PC})$ é habitualmente usado como parâmetro para o diagnóstico. Porém, como na maioria das vezes há alteração na forma e não no perímetro, sua utilização isolada pode levar a detecção tardia. As medidas do diâmetro ântero posterior (DAB) e bi auricular (DBA) parecem ser mais precisas. O objetivo do trabalho é analisar o valor do PC no diagnóstico, bem como o da razão entre as medidas DAP/ DBA.
\end{abstract}

received

December 12, 2016

accepted

February 23, 2017

published online

April 20, 2017
DOI https://doi.org/

10.1055/s-0037-1602692.

ISSN 0103-5355.
Copyright @ 2017 by Thieme Revinter

Publicações Ltda, Rio de Janeiro, Brazil
License terms

(c) (i) $\ominus$ (\$) 
Métodos Foram analisadas dados de 139 crianças já operadas no Biocor Instituto, em Minas Gerais. Os dados foram comparados com os parâmetros normais já conhecidos da população.

Resultados O PC não se alterou de maneira significativa nas craniossinostoses, seja como um grupo único ou nos subtipos. A razão das medidas DAP/ DBA alterou-se.

Conclusão $\mathrm{O} P C$ isolado parece não ser útil para o diagnóstico das craniossinostoses. A razão das medidas DAP/ DBA parecendo ter utilidade.

\section{Introduction}

Craniosynostosis is a well-known group of changes to the shape of the skull, secondary to the early fusion of the sutures. Those changes may cause restrictions in the development of some regions of the head, which are compensated for by abnormal growth in other areas.

The diagnosis of craniosynostosis is essentially clinical, based on the shape of the skull. Anthropometric data should be measured routinely by pediatricians during consultations to help the diagnosis. But, in the daily practice, it is common to use only the head circumference (HC) as a parameter, suggesting that, in the presence of a craniosynostosis, these data would be reduced because the skull does not grow satisfactorily. However, in most cases there is compensation in skull growth, resulting in a dysmorphic perimeter, but a normal HC. The measurement of the anteroposterior distance (APD) and the biauricular distance (BAD) could be more accurate, reflecting the changes in the shape of the head.

The aim of this work is to demonstrate the hole of those measurements in the diagnosis of the disease.

\section{Methods}

We analyzed the data from 129 children who had undergone surgical treatment for craniosynostosis at the Biocor Instituto, which were stored in the database of the surgical team. The data collected were age in months, sex, and anthropometric variables (HC, APD, and BAD) measured in centimeters by the traditional semiological technique. ${ }^{1}$ The children were classified into craniosynostosis subtypes, depending on the clinical presentation. The subtypes considered were trigonocephaly (closure of the metopic suture), scaphocephaly (closure of the sagittal suture), brachycephaly (closure of the coronal sutures bilaterally), plagiocephaly (closure of the coronal or lambdoid sutures unilaterally), oxycephaly (potential closure of all sutures) or mixed (closure of more than one suture).

The data were subjected to analysis using the Statistical Package for the Social Sciences (SPSS, IBM Corp., Armonk, NY, US) software. A comparison of the percentage of patients was performed with a frequency table and the chi-square test. ${ }^{2}$

The HC was regarded as decreased, normal or enlarged following the World Health Organization (WHO) criteria (http://www.who.int/childgrowth/standards/hc_for_age).
The APD/BAD ratio was considered normal or abnormal based on a theoretical assumption that the ratio of the measurements would be equal to 1 .

\section{Results}

Most of the children were male. The mean age was 10.5 months, with a median of 7 months.

Trigonocephaly was the most frequent subtype (49 cases), followed by scaphocephaly (31 cases), plagiocephaly (25 cases), brachycephaly (12 cases), oxycephaly (10 cases) and mixed ( 2 cases) (- Fig. 1 ).

The statistical analyses showed that there was a significant predominance of patients with a normal HC (-Fig. 2). Children with decreased or increased values of $\mathrm{HC}$ had the same statistical expression ( $\mathbf{- T a b l e ~} \mathbf{1}$ ).

The HC in the subtypes of craniosynostosis was also analyzed according to the parameters of normal and abnormal (-Table 2). Although there were numerical differences in the expression of normal or altered $\mathrm{HC}$ in the different subtypes, the number of children with decreased or increased values of HC was not significantly different (-Fig. 3 ).

Data showed that the frequency of patients with an abnormal APD/BAD ratio increased (- Table 3 ).

\section{Discussion}

Craniosynostosis is a group of changes to the shape and growth of the skull, secondary to the early partial or total fusion of one or more sutures of the calvaria and skull base. $^{3-5}$ Generally, changes in the function of the sutures cause restrictions in the development of some regions of the skull, which are compensated for by abnormal growth in other areas. ${ }^{6}$ According to the involvement of the sutures, several specific subtypes may develop. ${ }^{7}$

The etiology is still debated. Teratogenesis and environmental factors are known, but genetic involvement appears to be the most prevalent cause. ${ }^{6,8-10}$ As a consequence, the disease has a precocious presentation.

Craniosynostosis can result in serious consequences for the child. Changes in the shape of the skull can lead to aesthetic impairments with a variable intensity. Rejection of their appearance, social dumping and lack of emotional commitment are known secondary phenomena of these alterations. $^{11,12}$

Dysmorphisms may affect the cranial orbits, the base of the skull and the face, and lead to functional impairment. ${ }^{13}$ 


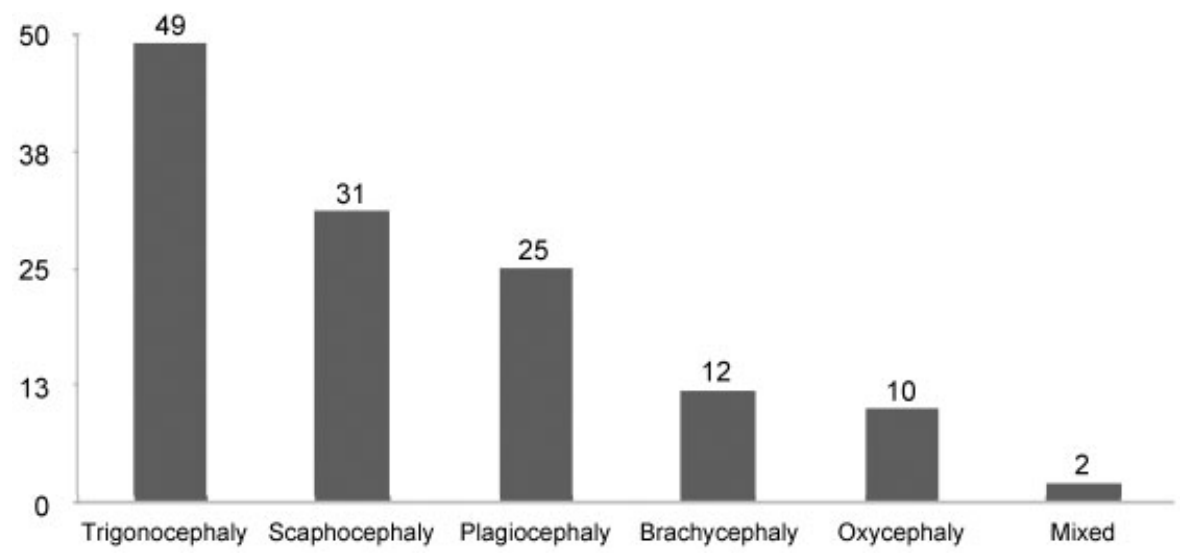

Fig. 1 Distribution of the subtypes of craniosynostosis.

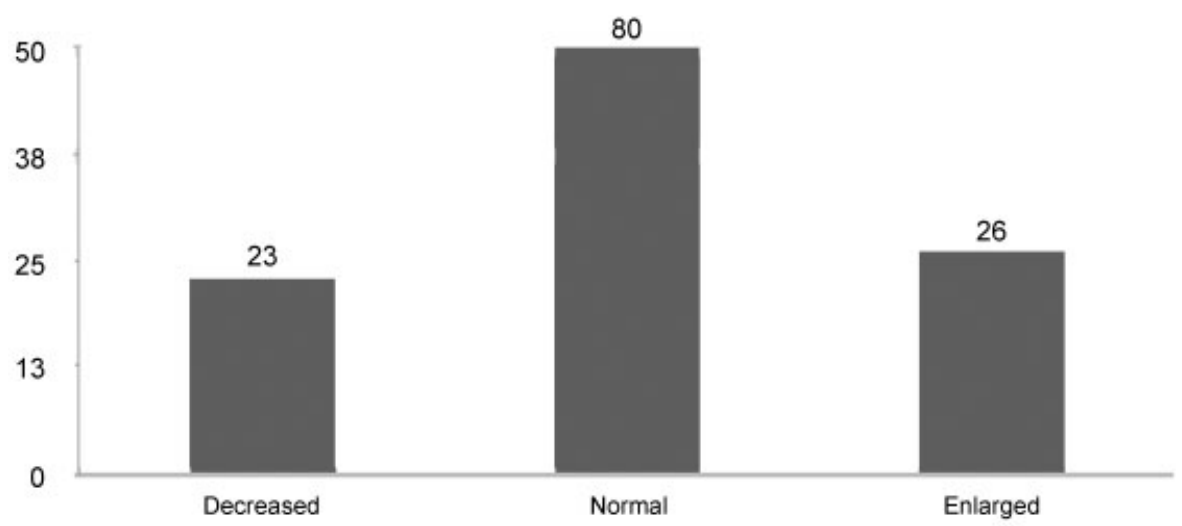

Fig. 2 Distribution by head circumference (HC).

Table 1 Statistical frequency of cases by head circumference

\begin{tabular}{|l|l|l|l|l|}
\hline \multicolumn{2}{|l|}{ Head circumference } & \multirow{2}{*}{ Total } & \multirow{2}{*}{$p$-value } \\
\cline { 1 - 3 } Decreased & Normal & Enlarged & & \\
\hline 23 & 80 & 26 & 129 & $<0.001$ \\
$(17.8 \%)$ & $(62.0 \%)$ & $(20.2 \%)$ & $(100 \%)$ & \\
\hline
\end{tabular}

Note: Chi-square test.

Table 2 Distribution by subtypes and head circumference

\begin{tabular}{|l|l|l|l|}
\hline \multirow{2}{*}{ Craniosynostosis } & \multicolumn{2}{|l|}{ Head circumference } & \multirow{2}{*}{ Total } \\
\cline { 2 - 3 } & Altered & Normal & \\
\hline Trigonocephaly & $15(30.6 \%)$ & $34(69.4 \%)$ & $49(100)$ \\
\hline Scaphocephaly & $18(58.1 \%)$ & $13(41.9 \%)$ & $31(100)$ \\
\hline Plagiocephaly & $6(24.0 \%)$ & $19(76.0 \%)$ & $25(100)$ \\
\hline Brachycephaly & $6(50.0 \%)$ & $6(50.0 \%)$ & $12(100)$ \\
\hline Oxycephaly & $3(30.0 \%)$ & $7(70.0 \%)$ & $10(100)$ \\
\hline Mixed & $1(50.0 \%)$ & $1(50.0 \%)$ & $2(100)$ \\
\hline p-value & 0.086 & - & - \\
\hline
\end{tabular}

Note: Chi-squared test.
Hypo- or hypertelorism, airway involvement and localized brain compression, especially in the posterior region, may follow these manifestations. ${ }^{14-16}$

There might also be restrictions to the growth of the skull. During the first year of life, such growth occurs significantly, following the exponential increase in the size of the brain. The restriction of this growth by the inefficient action of the sutures can lead to decreased cranial volume, with consequent chronic intracranial hypertension and injury, in varying degrees, to the infant brain. ${ }^{7,17,18}$

Surgical treatment is indicated for a significant portion of children with craniosynostosis to avoid the aforementioned consequences. The treatment should be performed early, even in the first months of life, to promote better cosmetic and functional results, and to prevent compression of the brain. ${ }^{6,19-22}$ In addition, the procedure is more aggressive, has more morbidity, and sometimes is less effective when performed later. ${ }^{22,23}$ However, for an early treatment, an even earlier diagnosis is necessary.

The diagnosis of craniosynostosis is essentially clinical, based on the shape of the skull. Pediatricians see the children in consultations in the first months, and have the opportunity to make an early diagnosis of the disease. Anthropometric data such as the HC, the APD and the BAD should be 


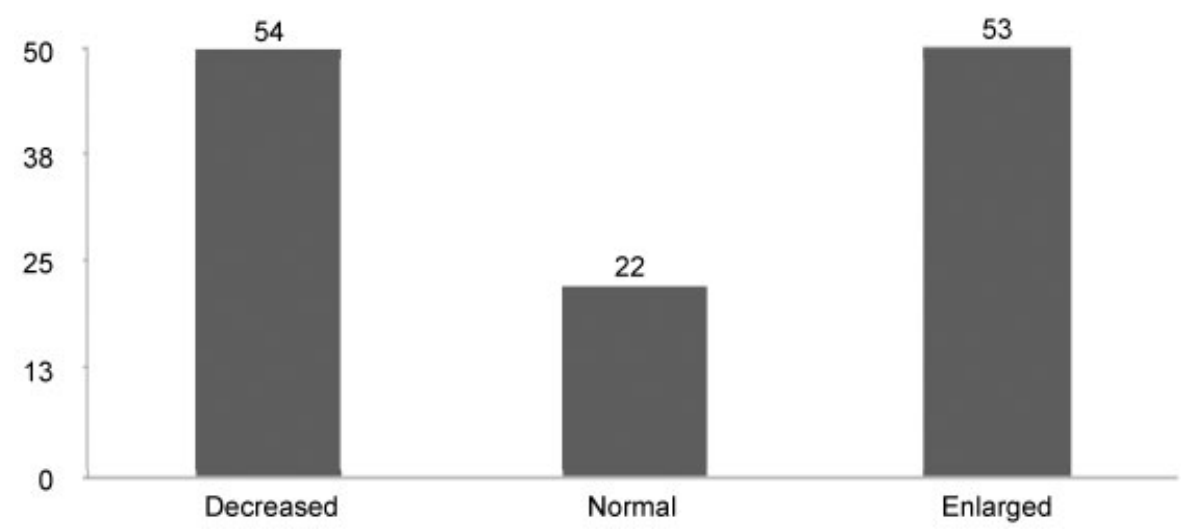

Fig. 3 Distribution by anteroposterior distance (APD)/biauricular distance (BAD) ratio.

Table 3 Comparison of the percentage of patients with normal APD/BAD ratios

\begin{tabular}{|l|l|l|l|}
\hline \multirow{2}{*}{} & \multicolumn{2}{|l|}{ Ratio APD/BAD } & \multirow{2}{*}{ Total } \\
\cline { 2 - 3 } & Normal & Altered & \\
\hline & $22(17.0 \%)$ & $107(83.0 \%)$ & $129(100 \%)$ \\
\hline$p$-value & 0.196 & - & - \\
\hline
\end{tabular}

Abbreviations: APD, anteroposterior distance; BAD, biauricular distance. Note: Chi-squared test.

measured routinely to help the diagnosis. However, in the daily practice, pediatricians commonly use the $\mathrm{HC}$ as a parameter, believing that in the presence of a craniosynostosis, these data would be reduced because the skull does not grow satisfactorily. However, in most cases there is compensation in the skull growth toward the closed suture, resulting in a dysmorphic perimeter, but a normal HC. ${ }^{24}$ This measurement also does not represent the intracranial volume. $^{21,25,26}$

The cranial dysmorphism resulting from asymmetric growth could indeed be confirmed by a change in the APD/BAD ratio. ${ }^{17,27}$ Those measurements, not universally used by the pediatricians, could be more precise for the diagnosis.

The analysis of the data showed that the gender of the children reflected the traditional knowledge, with craniosynostosis being more prevalent in boys. The age of the sample revealed the timing of the treatment, when the disease has become well manifested.

The incidence of the subtypes of craniosynostosis draws attention. Classically, scaphocephaly is the most frequent subtype. However, in our sample, trigonocephaly had the highest number of cases. This phenomenon has been previously observed in several services throughout the world, and has been considered a confirmed fact for some authors. ${ }^{28}$

The analysis of the data seems to show that there are distinct behaviors between them and the craniosynostosis. While the HC does not change, the APD and the BAD are altered in this disease.

The data related to the HC were analyzed considering craniosynostosis as a single disease, and considering each subtype separately. The $\mathrm{HC}$ is normal in the majority of cases, which is in contrast with the classical belief about craniosynostosis. There was a significant similarity in the number of children with increased and decreased HCs. This finding is also in contrast with the perception that the $\mathrm{HC}$ is decreased in craniosynostosis.

When analyzing the subtypes, we noted a predominance of HC changes in cases of scaphocephaly and brachycephaly, but such changes were not significant. Therefore, a normal $\mathrm{HC}$ is prevalent in all subtypes of craniosynostosis that were studied.

With the APD and the BAD, the perception is the opposite, as these measurements appear to be altered in craniosynostosis. The number of patients with increased or decreased APD/BAD ratio changed in the majority of cases. The statistical analysis of the data showed that these values were significant. Thus, the APD/DBP ratio was altered in craniosynostosis.

\section{Conclusions}

The analysis of the data suggests that in craniosynostosis, considered as a single disease, there is no significant change in the HC. The measurement does not change significantly, even when considering the subtypes individually.

Thus, this measurement should not be considered in isolation for the diagnosis of this disease.

Additionally, our study suggests that the APD/BAD ratio is altered in craniosynostosis. Therefore, the analysis of this ratio appears to be useful as a parameter for the diagnosis of this illness.

\section{Funding Source}

No external funding was secured for this study.

\section{Financial Disclosure}

All authors have no financial relationships relevant to this article to disclose. 


\section{Conflict of Interest}

All authors have no conflicts of interest to disclose. Institutional review board (IRB)/ethics committee and the human subjects assurance: COEP UFMG - \&CAAE: 10306913.8.0000.5149

\section{References}

1 Marcondes E. Normas para caracterização dos perímetros cefálico e torácico. Pediat (São Paulo) 1983;5:249-275

2 Triloa MF. Elementary Statistics: High School Edition. 9 ed: Addison-Wesley Educational Publishers, Incorporated; 2005

3 Delashaw JB, Persing JA, Broaddus WC, Jane JA. Cranial vault growth in craniosynostosis. J Neurosurg 1989;70(02):159-165

4 Foltz EL, Loeser JD. Craniosynostosis. J Neurosurg 1975;43(01): 48-57

5 Goodrich JT. Skull base growth in craniosynostosis. Childs Nerv Syst 2005;21(10):871-879

6 Lajeunie E, Barcik U, Thorne JA, El Ghouzzi V, Bourgeois M, Renier D. Craniosynostosis and fetal exposure to sodium valproate. J Neurosurg 2001;95(05):778-782

7 Persing PPSJA. Craniosynostosis. In: Andelson LAIPD, editor. Principals and Practice of Pediatric Neurosurgery. 1. New York: Thieme Medical Publishers Inc.; 1999. p. 219-42.

8 Johnson D, Wilkie AO. Craniosynostosis. Eur J Hum Genet 2011; 19(04):369-376

9 Merritt L. Recognizing craniosynostosis. Neonatal Netw 2009; 28(06):369-376

10 Wilkie AO, Byren JC, Hurst JA, et al. Prevalence and complications of single-gene and chromosomal disorders in craniosynostosis. Pediatrics 2010;126(02):e391-e400

11 Dake JA, Price JH, Telljohann SK. The nature and extent of bullying at school. J Sch Health 2003;73(05):173-180

12 Ozgur BM, Aryan HE, Ibrahim D, et al. Emotional and psychological impact of delayed craniosynostosis repair. Childs Nerv Syst 2006;22(12):1619-1623

13 Stavrou P, Sgouros S, Willshaw HE, Goldin JH, Hockley AD, Wake MJ. Visual failure caused by raised intracranial pressure in craniosynostosis. Childs Nerv Syst 1997;13(02):64-67
14 Baranello G, Vasco G, Ricci D, Mercuri E. Visual function in nonsyndromic craniosynostosis: past, present, and future. Childs Nerv Syst 2007;23(12):1461-1465

15 Clement R, Nischal K. Simulation of oculomotility in Craniosynostosis patients. Strabismus 2003;11(04):239-242

16 Hayward R. Venous hypertension and craniosynostosis. Childs Nerv Syst 2005;21(10):880-888

17 Weber J, Collmann H, Czarnetzki A, Spring A, Pusch CM. Morphometric analysis of untreated adult skulls in syndromic and nonsyndromic craniosynostosis. Neurosurg Rev 2008;31(02):179-188

18 Renier D, Sainte-Rose C, Marchac D, Hirsch JF. Intracranial pressure in craniostenosis. J Neurosurg 1982;57(03):370-377

19 Agrawal D, Steinbok P, Cochrane DD. Long-term anthropometric outcomes following surgery for isolated sagittal craniosynostosis. J Neurosurg 2006;105(5, Suppl)357-360

20 Inagaki T, Kyutoku S, Seno T, et al. The intracranial pressure of the patients with mild form of craniosynostosis. Childs Nerv Syst 2007;23(12):1455-1459

21 Kamdar MR, Gomez RA, Ascherman JA. Intracranial volumes in a large series of healthy children. Plast Reconstr Surg 2009;124(06): 2072-2075

22 Seruya M, Oh AK, Boyajian MJ, Posnick JC, Keating RF. Treatment for delayed presentation of sagittal synostosis: challenges pertaining to occult intracranial hypertension. J Neurosurg Pediatr 2011;8(01):40-48

23 Smyth MD, Tenenbaum MJ, Kaufman CB, Kane AA. The "clamshell" craniotomy technique in treating sagittal craniosynostosis in older children. J Neurosurg 2006;105(4, Suppl)245-251

24 Koizumi T, Komuro Y, Hashizume K, Yanai A. Cephalic index of Japanese children with normal brain development. J Craniofac Surg 2010;21(05):1434-1437

25 Netherway DJ, Abbott AH, Anderson PJ, David DJ. Intracranial volume in patients with nonsyndromal craniosynostosis. J Neurosurg 2005;103(2, Suppl)137-141

26 Sgouros S. Skull vault growth in craniosynostosis. Childs Nerv Syst 2005;21(10):861-870

27 Mota M, Melo A, Burak C, Daltro C, Rodrigues B, Lucena R. [Anthropometric cranial measures of normal newborn]. Arq Neuropsiquiatr 2004;62(3A):626-629

28 Di Rocco C, Massimi L. Focus Session "Changing epidemiology in pediatric neurosurgery”. Childs Nerv Syst 2009;25(07):785 